Prof. dr hab. Urszula ZAGÓRA-JONSZTA

Kolegium Ekonomii, Uniwersytet Ekonomiczny w Katowicach

e-mail: urszula.zagora-jonszta@ue.katowice.pl

ORCID: 0000-0003-4904-1025

DOI: $10.15290 /$ oes.2021.01.103.02

\title{
WIELKI KRYZYS GOSPODARCZY W OPINII „LEWIATANA” I GÓRNOŚLĄSKICH SFER WIELKOPRZEMYSLOWYCH ${ }^{1}$
}

\begin{abstract}
Streszczenie
Cel - Artykuł ma na celu prezentację postawy przedstawicieli i rzeczników sfer wielkoprzemysłowych II Rzeczypospolitej wobec wielkiego kryzysu gospodarczego. Zarówno wielki kapitał skupiony w Centralnym Zwiazku Polskiego Przemysłu, Górnictwa, Handlu i Finansów, zwanym „Lewiatanem”, jak i przemysłowcy górnośląscy, których interesy reprezentował Górnośląski Związek Przemysłowców Górniczo-Hutniczych, bronili się przed negatywnymi skutkami kryzysu, śląc do rządu petycje, w których domagali się: ulg podatkowych, zwolnienia z ceł, dotacji, zmniejszenia obciażeń socjalnych itp., w przeciwnym razie grożąc masowymi zwolnieniami pracowników. Jednocześnie szukali łatwiejszego przetrwania dekoniunktury w przyspieszonym procesie monopolizacji przemysłu.

Metoda badan - Zastosowano metodę analizy źródeł, metodę porównawczą oraz prostą metodę opisu.

Oryginalnośc/wartość - W artykule przytoczono wypowiedzi i publikacje przedsiębiorców oraz ich rzeczników, jak również raporty dotyczące postulatów przemysłowców pod adresem rządu. W tekście wykorzystano opracowania przedwojenne oraz powojennych historyków gospodarczych, jak też źródła archiwalne, zwłaszcza dotyczące sfer przemysłowych Górnego Śląska.
\end{abstract}

Słowa kluczowe: wielki kryzys, sfery wielkoprzemysłowe, monopolizacja, II Rzeczpospolita

\section{THE GREAT ECONOMIC CRISIS IN THE OPINION OF INDUSTRIAL SPHERES OF THE SECOND POLISH REPUBLIC ${ }^{2}$}

\section{Summary}

Pupose - The article aims to present the attitude of representatives and spokespersons of large-scale industrial spheres of the Second Polish Republic towards the great economic crisis. The large capital concentrated in the Central Union of the Polish Industry, Mining, Trade and Finance, called "Lewiatan", as well as the Upper Silesian industrialists, whose interests were represented by the Upper Silesian Association of Mining and Metallurgical Industrialists both defended themselves against the negative effects of the crisis. They sent petitions to the government in which they demanded tax

1 Artykuł wpłynął 20 lipca 2020 r., zaakceptowano 18 października 2020 r. Artykuł uzyskał wsparcie Ministerstwa Nauki i Szkolnictwa Wyższego w ramach dotacji na utrzymanie potencjału badawczego Kolegium Ekonomii Uniwersytetu Ekonomicznego w Katowicach.

2 The article received on 20 July 2020, accepted on 18 October 2020 . The article was supported by the Ministry of Science and Higher Education as a part of a grant for maintaining the research potential of the College of Economics, the University of Economics in Katowice. 
breaks, exemption from customs duties, subsidies, reduction of social burdens, etc., otherwise threatening with mass dismissals of employees. At the same time, they were looking for the easier survival of the recession in the accelerated process of monopolizing of the industry.

Research method - The source analysis method, comparative method and simple description method were used.

Originality / value - The article cites statements and publications of entrepreneurs and their spokespersons, as well as reports on industrialists' demands for the government. The text uses both pre-war and post-war economic historians studies as well as archival sources, especially regarding the industrial spheres of Upper Silesia.

Keywords: great crisis, large industrial spheres, monopolization, Second Polish Republic

JEL Classification: N0, O14

\section{Wstęp}

Kryzys gospodarczy lat 1929-1933 jest, jak dotąd, najgłębszym spośród wszystkich, które dotknęły gospodarkę rynkową. $\mathrm{Na}$ jego temat pisano wiele zarówno w okresie międzywojennym, jak też w okresie gospodarki socjalistycznej oraz współcześnie.

Celem artykułu jest prezentacja stanowiska kół wielkoprzemysłowych II Rzeczypospolitej wobec kryzysu. Zaprezentowano głosy przedstawicieli „Lewiatana”, organizacji reprezentującej interesy polskiego kapitału, jak również żądania przemysłowców górnośląskich, których do 1932 r. reprezentował Górnośląski Związek Przemysłowców Górniczo-Hutniczych, a następnie, po połączeniu Związku z „Lewiatanem", Unia Polskiego Przemysłu Górniczo-Hutniczego. Zarówno przemysłowcy, jak i ich rzecznicy często zabierali głos, broniąc interesów wielkiego kapitału. Słali petycje do rządu, domagając się różnych form pomocy, np. ulg podatkowych i dotacji.

W tekście wykorzystano zarówno źródła przedwojenne, jak i współczesne. Sięgnięto również do źródeł archiwalnych i prasowych.

\section{2. „Lewiatan” wobec wielkiego kryzysu}

Wielki kapitał był skupiony w Centralnym Związku Polskiego Przemysłu, Górnictwa, Handlu i Finansów, zwanym „Lewiatanem”, powołanym do życia 15 grudnia 1919 r. W momencie najgłębszego załamania koniunktury, 8 maja 1932 r., połączył się on z Górnośląskim Związkiem Przemysłowców Górniczo-Hutniczych (GZPGH) reprezentującym interesy kapitału górnośląskiego i utworzył Centralny Związek Polskiego Przemysłu (CZPP). Przez cały okres międzywojenny dyrektorem „Lewiatana” był Andrzej Wierzbicki, autor wielu śmiałych wystąpien, wspaniały mówca, dbający o interesy sfer wielkoprzemysłowych. Główne hasło „Lewiatana” brzmiało: rząd powinien być liberalny i nie wtrącać się do gospodarki, poza protekcjonizmem i troską o rentowność gospodarki prywatnej. W ciagu 20 lat istnienia II Rzeczypospolitej Wierzbicki wielokrotnie atakował przedstawicieli rządu 
za niewłaściwą (czytaj: nieodpowiadająca wielkiemu przemysłowi) politykę gospodarcza, domagając się jednocześnie pomocy w postaci: ulg podatkowych, subwencji i dotacji z budżetu dla prywatnych inwestycji, podwyżki ceł ochronnych czy embarga na import niektórych konkurencyjnych towarów. Te żądania nasiliły się zwłaszcza w okresie wielkiego kryzysu.

W Polsce kryzys pojawił się z pewnym opóźnieniem, bo dopiero z początkiem 1930 roku. Jeśli przyjąć wskaźnik produkcji przemysłowej w 1929 r. za 100, to w następnych latach wynosił odpowiednio: 1930 - 82, 1931 - 69, 1932 - 54, 1933 56, 1934- 63, 1935 - 66 [Landau, Tomaszewski, 1962, s. 161].

Oskarżywszy rząd o brak skutecznego programu walki z kryzysem³, „Lewiatan” opracował własny program antykryzysowy, który ogłosił w listopadzie 1932 r. Jego naczelną dewiza było zabezpieczenie interesów wielkiego kapitału. Domagano się: likwidacji podatku majątkowego, zreformowania podatku spadkowego i dochodowego w postaci niepobierania go w czasie kryzysu, ograniczenia zatrudnienia, obniżenia płac i przedłużenia dnia pracy, zmniejszenia składek na ubezpieczenia społeczne [Program..., 1933, s. 20-22]. Wierzbicki dowodził, że fiskalizm skarbowy w okresie kryzysu pogarsza i tak trudną sytuację przedsiębiorców. Wnioskował więc o umorzenie zaległości podatkowych i nałożenie ceł na towary importowane w celu ochrony rodzimej produkcji [Wierzbicki, 1933, s. 73]. Proponowany sposób oddłużenia przemysłu zakładał: obniżenie stopy procentowej, likwidację zaległych składek na ubezpieczenia, zwolnienie z podatków procentów od wkładów bankowych, uznanie za obrót jedynie wpływów gotówkowych i pobieranie tylko od nich podatku obrotowego. Program zakładał również zmniejszenie obciążeń socjalnych i ograniczenie zatrudnienia $\mathrm{w}$ niepełnym wymiarze godzin, ponieważ zwiększało to koszty robocizny. „Obecny poziom płac realnych pozwala na dalszą obniżkę, za pomocą której może być przeprowadzona skuteczna redukcja kosztów własnych przemysłu" [Program..., 1933, s. 142] - słowa te brzmią ironicznie w zestawieniu z wydatkami robotników. Na skutek wzrostu bezrobocia i zatrudniania w niepełnym wymiarze czasu pracy dochody społeczeństwa spadały. Jak podaje Maly rocznik statystyczny [1936, s. 192, tab. 35], miesięczny wydatek czteroosobowej rodziny bezrobotnego wynosił przeciętnie 19 zł, podczas gdy taka sama rodzina urzędnika wydawała średnio 128 zł. W latach 1929-1933 bezrobocie wzrosło dziesięciokrotnie (w roku 1929 stopa bezrobocia była najniższa w całym dwudziestoleciu).

Ze względu na to, że w latach kryzysu rozwarły się mocno tzw. nożyce cen (ceny artykułów rolnych spadły przeciętnie od 50 do 70\%) [Roszkowski, 2004, s. 64], czyli różnica między cenami towarów przemysłowych a produktów rolniczych, społeczeństwo domagało się obniżki cen tych pierwszych. Przedstawiciele wielkiego przemysłu dowodzili, że żądanie obniżki cen wyrobów przemysłowych jest „,absurdem gospodarczym”. „Nie można cen obniżyć, jeśli daniny publiczne i socjalne są nietykalne, jeśli nietykalne są taryfy kolejowe i płace, jeżeli produkcja musi utrzymać

\footnotetext{
3 W październiku 1932 r. rząd podjał kroki antykryzysowe w postaci: obniżenia cen towarów zmonopolizowanych, oddłużenia kapitałów i organizowania robót publicznych [Landau, Roszkowski, 1995, s. 196].
} 
zbędne załogi robotnicze" [Program..., 1933, s. 28]. Przemysłowcy żądali więc obniżki taryf kolejowych, tłumacząc, że bez tego nie będzie można obniżyć cen artykułów przemysłowych [Program..., 1933, s. 33]. Krytykując ,,jaskrawy przykład fiskalizmu” rządu wobec przemysłu, w stosunku do rolnictwa „Lewiatan” zakładał tylko odroczenie długów, a nie ich umorzenie [Program..., 1933, s. 15].

Domagano się większej elastyczności w zakresie ustalania długości dnia roboczego, płac i urlopów tak, by właściciele fabryk mieli większe możliwości manewru. Program wspierało wielu rzeczników sfer przemysłowych, między innymi: Henryk Tennenbaum, Tadeusz Bernadzikiewicz, Roger Battaglia, Maurycy Ignacy Poznański. Ten ostatni wyszedł z propozycja, aby w pewnych okresach gospodarczych przemysłowcy nie musieli odprowadzać zysków do skarbu państwa i by mogli wtedy kompensować straty jednych lat zyskami drugich, ponieważ to się państwu opłaci, bo przyczyni się do wzmocnienia przemysłu [Poznański, 1933, s. 57]. Uważał też, że świadczenia społeczne sa za wysokie: „Z punktu widzenia państwowego, świadczenia socjalne powinny być tylko tak daleko rozbudowane, aby brak ich nie wywołał wrzenia wewnętrznego, który by mógł zaszkodzić sile państwowej. Nie ulega żadnej kwestii, że u nas przekroczono rozsądna granicę w rozwoju świadczeń socjalnych i to nawet w sposób wybitny" [Poznański, 1933, s. 64]. Przy podsumowaniu debaty wokół programu Wierzbicki pisał: „W piękny słoneczny dzień niech ogłoszone będzie, że począwszy powiedzmy od 1 stycznia 1933 roku wszystkie zaległości (...) w podatkach państwowych, samorządowych, podatkach na rzecz skarbu śląskiego, we wpłatach na rzecz instytucji ubezpieczeniowych ulegają zawieszeniu, a przypadające od nich odsetki i kary za zwłokę zostają umorzone. Tę radosna wieść przyjmie z jednakową ulgą i aparat skarbowy i całe życie gospodarcze" [Program..., 1933, s. 79-80]. Wówczas wszyscy nabiorą chęci do dalszej pracy, co przełoży się na rozwój gospodarczy - sugerowano.

Program wywołał burzliwą dyskusję w społeczeństwie. W prasie pojawiły się artykuły zarówno popierające, jak i krytykujące postulaty „Lewiatana”. Ostrym krytykiem programu był Stefan Starzyński, urzędnik państwowy wyższego szczebla (m.in. wiceminister skarbu), późniejszy prezydent Warszawy, który na łamach „Polski Gospodarczej” - organu rządowego - pisał o „mistrzowsko przeprowadzonym" ataku na politykę rządu w dziedzinie zaległości podatkowych [Starzyński, 1932b, 1932c]. Obnażył prawdziwe oblicze programu polegającego na przeciwstawieniu się obniżce cen artykułów przemysłowych. Dowodził, że obrona sztywności cen kartelowych jest prowadzona poprzez atak na rzekomo sztywne składniki kosztów, które należało obniżyć. Zarzucał programowi, że nie uwzględnia trudnej sytuacji w rolnictwie, skupiając się jedynie na przemyśle [Starzyński, 1932a]. Wierzbicki polemizował z nim, broniąc programu i dowodząc jego skuteczności.

W latach kryzysu nasiliła się również krytyka pod adresem etatyzmu. Sfery przemysłowe oskarżały rząd o nieuczciwą konkurencje $z$ sektorem prywatnym w postaci zakładania własnych przedsiębiorstw, które funkcjonowały w uprzywilejowanych warunkach i korzystały często z pomocy państwa. Na dodatek ich rentowność stała pod znakiem zapytania. T. Bernadzikiewicz dowodził, że są one nierentowne, a w latach kryzysu państwo rozszerza swoją działalność inwestycyjna. 
Dlatego należy ograniczyć działalność państwa do tych obszarów, w które inicjatywa prywatna nie chce wejść, a ze względów społeczno-gospodarczych są potrzebne. Jego zdaniem przedsiębiorstwa państwowe muszą działać w takich samych warunkach jak prywatne; ich uprzywilejowanie jest szkodliwe. Uważał, że państwo „zbyt łatwo rezygnuje z popierania i pielegnowania inicjatywy prywatnej na rzecz własnej działalności gospodarczej" [Bernadzikiewicz, 1935, s. 149]. Skuteczniejsze byłoby odpowiednie pobudzenie prywatnej przedsiębiorczości. Ponieważ jednak przemysłowcy słali petycje do rządu o ulgi, zwolnienia z opłat i dotacji, które wyraźnie przybrały na sile w latach kryzysu, krytyka polityki rządu nie mogła się posunąc za daleko. Proponował więc tylko ich reformę i usunięcie przerostów [Bernadzikiewicz, 1937]. Na łamach „Przeglądu Gospodarczego”, organu CZPP, ukazało się sporo jego artykułów krytykujących nadmierny i niewłaściwy interwencjonizm państwa. Wielki przemysł mówił „nie” ingerencji państwa mogącej ukrócić jego swobodę i ograniczyć nadmierne zyski, a jednocześnie „tak”, gdy była nastawiona na pomoc inicjatywie prywatnej. Jan Kofman [1986, s. 184] takie stanowisko nazwał quaziliberalizmem.

\section{Przemysł górnośląski wobec kryzysu}

\subsection{Produkcja, zatrudnienie i „polonizowanie” przemysłu na Górnym Śląsku}

Z chwilą przyłączenia Górnego Śląska do Polski wielki przemysł w $75 \%$ należał do Niemców, również 86\% wielkiej własności ziemskiej było w ich rękach. Zgodnie z założeniami konwencji genewskiej, strona polska przez 15 lat nie mogła ograniczać stanu posiadania wielkich rodów górnośląskich arystokratów: Plessów, Henckel-Donnersmarków, Hohenlohe-Ingelfingerów oraz przywilejów i koncesji nabytych przed zmiana suwerenności. Przemysł górnośląski dotkliwie odczuł skutki kryzysu, który pojawił się tu dopiero pod koniec pierwszego kwartału $1930 \mathrm{r}$. W tabeli 1 przedstawiono spadek produkcji przemysłowej w odniesieniu do 1928 roku.

TABELA 1

Produkcja wybranych wyrobów w polskiej części Górnego Śląska

w latach 1929-1933 (rok 1928=100)

\begin{tabular}{|l|c|c|c|c|c|}
\hline Rok & $\begin{array}{c}\text { Wydobycie } \\
\text { węgla } \\
\text { kamiennego }\end{array}$ & $\begin{array}{c}\text { Produkcja } \\
\text { surówki } \\
\text { żelaza }\end{array}$ & $\begin{array}{c}\text { Produkcja } \\
\text { stali }\end{array}$ & $\begin{array}{c}\text { Produkcja } \\
\text { cynku }\end{array}$ & $\begin{array}{c}\text { Produkcja } \\
\text { ołowiu }\end{array}$ \\
\hline 1929 & 112,4 & 102,7 & 95,5 & 104,6 & 96,6 \\
\hline 1930 & 92,5 & 69,8 & 96,4 & 112,6 & 108,5 \\
\hline 1931 & 94,4 & 57,4 & 60,5 & 88,0 & 84,7 \\
\hline 1932 & 70,6 & 32,0 & 27,8 & 60,0 & 31,8 \\
\hline 1933 & 65,5 & 51,6 & 62,6 & 58,9 & 32,7 \\
\hline
\end{tabular}

Źródło: [Urz̨ad Wojewódzki Ślaski..., sygn. 232, s. 33-38; sygn. 1303 II, s. 310]. 
Jak wynika $\mathrm{z}$ danych przedstawionych $\mathrm{w}$ tabeli 1 , parametry wszystkich najważniejszych pozycji przemysłowych mocno spadły, co świadczy o dotkliwym pogorszeniu się kondycji górnośląskiego przemysłu. Poprawa koniunktury od 1933 r. nie objęła jednak przemysłu węglowego i cynkowego Śląska, gdyż - jak widać - wydobycie węgla osiagnęło wtedy najniższy poziom; najmocniej spadła też produkcja cynku. Górnictwo odnotowało spadek eksportu węgla na rynki skandynawskie, bałtyckie oraz środkowoeuropejskie. Zapotrzebowanie wzrosło tylko na rynku krajowym pod wpływem dobrze zorganizowanej akcji marketingowej.

Koniunktura gospodarcza wyznaczała wielkość zatrudnienia, które najwyższy poziom osiagnęło w 1929 r. - 199 tys. osób. Najniższy poziom zanotowano w roku 1933 - niewiele ponad 101 tys. Różnica prawie 100 tys. osób między najwyższym a najniższym poziomem zatrudnienia świadczy o głębokości kryzysu. Najdotkliwiej jego skutki odczuli pracownicy: górnictwa, przemysłu hutniczego, maszynowego i budownictwa. Stosunkowo najmniejsze ograniczenia wystapiły w przemyśle spożywczym i odzieżowym. Według danych Ślaskiego Urzędu Wojewódzkiego, liczba bezrobotnych w okresie wielkiego kryzysu wahała się od 52,1 tys. w roku 1930 do 132,4 tys. w 1933. Jeśli do tego dodać rodziny bezrobotnych, które także cierpiały z powodu bezrobocia, liczba dotkniętych tym nieszczęściem wzrastała do 320 tys. osób [Urząd Wojewódžki Ślaski..., sygn. 2500 i 2635].

Wielki kryzys gospodarczy uaktywnił pomysłowość śląskich przemysłowców. Sięgali oni do różnych form częściowego zatrudnienia. Stosowali zatrudnienie przez część tygodnia, co oczywiście wiązało się ze spadkiem płacy oraz tzw. świętówki (nieopłacone przerwy w pracy). W $1930 \mathrm{r}$. stanowily one $15 \% \mathrm{w}$ stosunku do należnych dniówek, w 1931 - 11,6\%, w 1932 - 25,06\%, a w 1933 r. - 19,8\% [Urz̨qd Wojewódzki Ślaski..., sygn. 1310, s. 49; sygn. 52, s. 1; sygn. 224, s. 103-105]. Częstą forma zatrudnienia było zatrudnienie „za rewersem”, polegające na przejściowym, jedno- lub dwumiesięcznym zatrudnieniu i następnie zwolnieniu pracownika za jego pisemna zgodą. Ta forma była szczególnie uciążliwa, ponieważ odbierała pracownikom niektóre uprawnienia, np. dodatki rodzinne, prawo do urlopu czy ubezpieczenia. Stosowano także tzw. urlopy turnusowe, które trwały nawet kilka miesięcy [Pabisz, 1956, s. 511-528]. W ekstremalnych przypadkach zamykano całe zakłady pracy: kopalnie, huty i mniejsze przedsiębiorstwa albo likwidowano niektóre wydziały. Wszystkie te działania skutkujące ograniczeniem zatrudnienia wpływały negatywnie, choć w różnym stopniu, na ekonomiczną kondycję robotników. W najgorszej sytuacji znaleźli się ci, którzy zostali całkowicie zwolnieni z pracy.

Potęgujący się z biegiem czasu nacisk rządu na koncerny zmierzał na Górnym Śląsku do ich formalnego przynajmniej spolonizowania przez wprowadzenie języka polskiego w administracji i obsadzenie stanowisk polskimi urzędnikami. Często przedsiębiorstwa należące do kapitału niemieckiego ubierano w „polskie szaty” przez powoływanie na stanowiska kierownicze przedstawicieli polskich sfer gospodarczych. Lista Polaków, którzy w ten sposób „polonizowali” niemiecki przemysł, 
była długa ${ }^{4}$. Ludzie ci, mający powiązania z rządem, często występowali jako rzecznicy obcego kapitału, wykorzystując swoje wpływy. Jak z pogardą wyraził się o nich minister przemysłu i handlu Ferdynand Zarzycki na jednym z posiedzeń sejmowych - były to „szmaty”, których kilkadziesiąt miał zapisanych u siebie w notesie [Ivanka, 1964, s. 125].

\subsection{Sfery przemysłowe na Górnym Śląsku wobec kryzysu}

Przemysł ciężki na Górnym Śląsku miał swoją reprezentację w postaci wspomnianego wcześniej Górnośląskiego Związku Przemysłowców Górniczo-Hutniczych. Początkowo miała ona wyraźnie antypolskie nastawienie, jednak w miarę upływu czasu, kiedy nadzieje na Polskę jako państwo sezonowe topniały, przemysłowcy starali się pozyskać przychylność władz śląskich i centralnych (Związek miał swoją delegaturę w Warszawie). GZPG-H afiliował Związek Pracodawców Górnośląskiego Przemysłu Górniczo-Hutniczego powołany do ochrony interesów pracodawców (ustalał zasady rekrutacji i zatrudniania robotników, wysokość płac, redukcję zatrudnienia, pomoc zakładom objętym strajkami). Prowadził też działalność prasową („Przemysł i Handel Górnośląski” oraz prasa korfantowska). Po połączeniu GZPG-H z „Lewiatanem”, reprezentantką przemysłu górnośląskiego, Zagłębia Dąbrowskiego i Krakowskiego została Unia Polskiego Przemysłu Górniczo-Hutniczego, w której kierownictwie nie mogli zasiadać Niemcy.

Niezależnie jednak od zmian organizacyjnych, polityka gómośląskich sfer przemysłowych nadal skupiała się na obronie własnych interesów. W latach kryzysu narzekano na zbyt wysokie przywileje robotników, wynikające z niemieckiego ustawodawstwa socjalnego, które obciążaja przemysł górnośląski i utrudniaja

\footnotetext{
${ }^{4}$ Dla przykładu można wymienić: Henryka Askenazego - dyrektora Banku Dyskontowego w Warszawie, Brunona Sikorskiego - dyrektora Rady Naczelnej Kupiectwa Polskiego i posła, Artura Benisa docenta ekonomii AGH, pełnomocnika rządu do rokowań z Francją na temat wpuszczenia kapitału francuskiego na Górny Śląsk, Konstantego Wolnego - marszałka Sejmu Śląskiego, biskupa Stanisława Adamskiego, Antoniego Nosowicza - byłego ministra kolei, dyrektora spółki handlu węglem „Cäsar Wolheim”, Zygmunta Seydę - byłego wiceministra i marszałka Sejmu, szefa warszawskiej delegatury Górnośląskiego Związku Przedsiębiorców Górniczo-Hutniczych, Mariana Szydłowskiego - byłego ministra przemysłu i handlu, następcę M. Seydy, Józefa Kiedronia - byłego ministra przemysłu i handlu czy Wojciecha Korfantego - człowieka wpływowego, posła, czołową postać śląskiej sceny politycznej. Do tego grona dołączyli też przedstawiciele wyższych sfer, między innymi: hrabia Alfred Potocki - właściciel Łańcuta, członek rady nadzorczej Zjednoczonych Hut „Królewska” i „Laura”, hrabia Paweł Sapieha - członek rady nadzorczej Huty „Silesia” w Paruszowcu k. Rybnika czy książę Stanisław Lubomirski z Warszawy [Grzyb, 1978, s. 68-70]. Wśród polskich nazwisk firmujących kapitał niemiecki na uwagę zasługuje również Alfred Falter - najbogatszy polski przedsiębiorca II Rzeczypospolitej, który był członkiem wielu rad nadzorczych oraz generalnym dyrektorem największego koncernu handlu węglem „Robur”, będącego wcześniej koncernem niemieckim. Formalne zmiany właścicieli (obok Faltera dokooptowano jeszcze dwóch Polaków: Kramsztyka i Wachowiaka) oraz nazwy firmy nie wpłynęły na zmianę składu kapitałowego i nie ograniczyły wpływów niemieckich. Marian Szydłowski - wicedyrektor „Lewiatana” - wspominał, iż na jednym z rautów podczas pobytu w Belgii został przedstawiony księżnej Hohenlohe, która dowiedziawszy się, że jest z Górnego Śląska, powiedziała: „ja mam tam też coś niecoś, ale tym to się zajmuje ten poczciwy Flick. Pan rozumie tę drabinkę: my a Falter, Falter a Flick, Flick a księżna Hohenlohe” [Ivanka, 1964, s. 125].
} 
konkurencję z przemysłem pozostałych dzielnic kraju [Ślosarczyk, 1936]. Negatywnie oceniono skutki polityki deflacyjnej, która mocno dotknęła przemysł Górnego Śląska, ponieważ skupiała się głównie na obniżaniu cen wielkiego przemysłu [Dangel, 1936]. Kiedy w czerwcu 1932 r. przybył do Katowic minister przemysłu $i$ handlu F. Zarzycki, przywitały go słowa podziękowania za pomoc rządu dla górnośląskiego przemysłu i prośby o jej dalszą kontynuację przynajmniej w dotychczasowych rozmiarach. Przemysłowcy zwrócili się też z prośbą o opiekę nad śląskim handlem w warunkach coraz większego zagrożenia ze strony konkurencji. Ponieważ rząd zgodził się na wprowadzenie ulg podatkowych w stosunku do zalegających podatników, śląscy przemysłowcy zaproponowali objęcie ulgami bieżących należności, tłumacząc, że opieszałych podatników jest tu bardzo niewielu [Desyderaty przemystu..., 1932]. Alfred Falter, dyrektor Związku Górnośląskich Kopalń „Robur”, dowodził, że dalsza obniżka cen węgla spowoduje załamanie się górnictwa i należy powstrzymać rząd od takich decyzji [Protokót z.posiedzenia..., 1932b]. Domagano się również obniżki taryf kolejowych, zarobków i świadczeń socjalnych [Protokót zposiedzenia..., 9.06.1933]. Korzystając z obecności ministra w Katowicach w 1934 r., postanowiono „podkreślić mocno fakt upośledzenia dużych przedsiębiorstw w stosunku do przedsiębiorstw małych, jak również wysunąc te propozycje, które mogłyby ułatwić przemysłowi dalsza egzystencję" [Protokót z posiedzenia..., 1934]. Na posiedzeniu w lutym następnego roku zwrócono uwagę na konieczność większego propagowania stanowiska Unii w społeczeństwie, np. poprzez urządzanie wieczorów dyskusyjnych w Warszawie, ewentualnie również w Katowicach. W rezultacie zdecydowano, by powołać do życia Komitet Prasowy, który zająłby się organizacja propagandy [Protokót z posiedzenia..., 1935a]. W październiku 1935 r. Komisja Gospodarcza Unii opracowała tezy programu, w których postulowano konieczność utrzymania:

- równowagi budżetowej poprzez daleko idące oszczędności,

- stałości waluty,

- deflacji, która powinna dotyczyć całej gospodarki, nie tylko cen i uwzględniać rentowność przedsiębiorstw [Protokót zposiedzenia..., 1935b].

Sfery przemysłowe Górnego Śląska były początkowo bardziej wyrozumiałe wobec przejawów interwencjonizmu państwowego niż ich koledzy z „Lewiatana”. W sprawozdaniu z działalności Unii za rok 1933 czytamy: „Jest rzeczą zrozumiała, że w zmienionych warunkach, w jakich gospodarstwo narodowe Polski żyje obecnie, liberalizm gospodarczy nie spełniłby swego zadania: polska ekspansja gospodarcza spotkałaby na swej drodze przeszkody, które (...) nie byłyby do przezwyciężenia w drodze wysiłków indywidualnych, bez poparcia państwa. Ingerencja państwa jest więc niezbędna, chodzi tylko o to, aby była ona ograniczona do rzeczywistych potrzeb" (czyli zgodnych z interesem wielkiego przemysłu). Ponieważ jednak wkraczała ona we wszystkie dziedziny życia gospodarczego (reglamentacja cen, wytwórczości, przymus organizacyjny, system koncesjonowania itp.), stawała się niebezpiecznym etatyzmem, którego przemysłowcy się obawiali [Sprawozdanie zdziałalności Unii..., 1934, s. 1-2]. W sprawozdaniu za rok 1934 zapisano natomiast: „W dziedzinie ogólnogospodarczych zagadnień staliśmy nadal niezmiennie na stanowisku 
liberalizmu gospodarczego, dążąc, w miarę możliwości - do ograniczenia rozmiarów i czasu trwania interwencjonizmu państwowego, narzuconego zresztą Polsce, podobnie jak i innym państwom, w pewnej mierze przez specyficzne warunki obecnego kryzysu" [Sprawozdanie z driatalności Unii..., 1935, s. 1]. W kolejnym sprawozdaniu znalazła się już jawna krytyka polityki deflacyjnej, którą rząd, zdaniem śląskich przemysłowców, prowadził w sposób nierównomierny i niesynchronicznie. Dotyczyła ona głównie cen przemysłowych, a zwłaszcza cen artykułów skartelizowanych, nie obejmując rzekomo w ogóle płac roboczych i urzędniczych. W rezultacie produkcja przemysłowa stała się nierentowna, inwestycje zanikły. „Ingerencja państwa w sprawy życia gospodarczego przybrała takie rozmiary i tego rodzaju formy, że o jakiejkolwiek swobodnej działalności kierowników zakładów produkcyjnych i o jakiejkolwiek swobodnej dyspozycji tymi zakładami, zwłaszcza w dziedzinie wielkiego przemysłu, nie mogło być mowy" [Sprawozdanie z driałalności Unii..., 1936, s. 2].

Przemysłowcy górnośląscy prowadzili twarde rozmowy z przedstawicielami rządu. Ze sprawozdań z działalności GZPG-H w okresie kryzysu na pierwszy plan wysuwa się kwestia powetowania strat, jakie poniósł przemysł ciężki Górnego Śląska. Dla przykładu: dewaluację funta brytyjskiego mocno odczuł przemysł węglowy. W rezolucji przedłożonej rządowi w październiku 1931 r. czytamy, iż przemysł ten zobowiązal się utrzymać eksport węgla droga morską na dotychczasowym poziomie (800 tys. ton miesięcznie) w zamian za kredytowanie mu opłat przewozowych przez rząd [Sprawozdanie z driatalności Górnoślaskiego..., 1931, s. 4-5].

Śląski przemysł domagał się również większych zamówień rządowych, podkreślając, że są one nierównomiernie rozdzielane ze szkodą dla województwa śląskiego. Rząd w Warszawie nie zawsze uwzględniał przemysł górnośląski przy rozdzielaniu zamówień, wyraźnie preferując kapitał prywatny z innych dzielnic Polski.

Biorąc pod uwagę to, że robotnicy górnośląscy nie posiadali działek ziemi, w przeciwieństwie do robotników z innych regionów kraju, ich położenie, zdaniem przemysłowców, było o wiele gorsze [Notatka..., 1931, s. 38]. Ten wątek pojawiał się często w oficjalnych wystapieniach sfer przemysłowych Górnego Śląska na spotkaniach z przedstawicielami władz wojewódzkich i centralnych. Śląscy przemysłowcy mieli też orędownika w osobie Wojciecha Korfantego, który na łamach swoich dzienników - katowickiej „Polonii” i warszawskiej „Rzeczpospolitej” walczył o zamówienia. Uważał, że w pierwszej kolejności rząd powinien udzielać zamówień przemysłowi górnośląskiemu, ponieważ sytuacja gospodarcza tego regionu jest szczególnie trudna ze względu na wysoki poziom industrializacji i duże skupisko robotników. W agitacji na rzecz zamówień rządowych poparła Korfantego Komisja Pracy i Opieki Społecznej Sejmu Śląskiego. W wydanej rezolucji postulowała: „Sejm Śląski wzywa Pana Wojewodę, ażeby poczynił starania u rządu Rzeczypospolitej Polskiej, by zamówienia rządowe w pierwszym rzędzie przydzielono przemysłowi górnośląskiemu" [Sprawozdania Stenograficzne..., 1932, s. 14].

We wrześniu 1933 r. odbył się w Katowicach zjazd działaczy gospodarczych i społecznych województwa śląskiego, w którym uczestniczyło około półtora tysiąca osób, reprezentujących wszystkie warstwy społeczne i gospodarcze. Na zjeździe 
obecny był wojewoda Michał Grażyński oraz wiceminister przemysłu i handlu Tadeusz Lechnicki, który podkreślił znaczenie regionu śląskiego w gospodarce Polski. W swoim przemówieniu zaznaczył konieczność walki z kryzysem poprzez: zwiększenie eksportu, poprawę chłonności rynku wewnętrznego, obniżkę cen przemysłowych, ustalenie dla każdego przedsiębiorstwa przydziału zamówień, zrównanie koncernów z innymi podmiotami, ujawnienie cen, zarobków oraz umów kupna i sprzedaży węgla, co uniemożliwi szkodliwe przyznawanie tajnych rabatów i ukrywanie prawdziwych wyników operacji finansowych przedsiębiorstw [Zjazd..., 1933, s. 21-26]. Tezy Komisji Przemysłowej przedstawione na zjeździe uwzględniały działania zmierzające do unarodowienia kapitału w Polsce, w tym zwłaszcza na Śląsku, rewizję całokształtu stosunków finansowych z zagranica, zwłaszcza z Niemcami oraz obciążeń przemysłu z tytułu pożyczek, które w wielu wypadkach miały na celu tylko uszczuplenie podatku dochodowego i zapewnienie sobie zysków przy oficjalnym braku dochodów. Postulowano również zniesienie koncernów węglowych, by ujednolicić zasady gospodarki węglowej wewnątrz kraju oraz w eksporcie i utworzyć jedno biuro sprzedaży kontrolowane przez rząd [Zjąd..., 1933, s. 60-62]. Te postulaty nie mogły się podobać górnośląskim sferom przemysłowym, które od początku słały petycje do rządu polskiego o ulgi, uprawnienia i rozmaite przywileje. Przykładem może być wizyta prezesa Banku Gospodarstwa Krajowego Romana Góreckiego na Śląsku w 1934 r. w związku z lustracją oddziału Banku w Katowicach, po której odbyła się konferencja z udziałem sfer przemysłowych, władz wojewódzkich i członków rady nadzorczej BGK. Posypały się wówczas prośby o szersze finansowanie górnośląskiego przemysłu i nawiązanie ściślejszej współpracy rządu ze śląskimi sferami gospodarczymi. R. Górecki zapewnił dość ogólnikowo, że „postulaty sfer gospodarczych Ślasska spotkają się z uznaniem czynników rządowych" [Pismo..., 1934, s. nlb] ${ }^{5}$.

Nieco łagodniej podchodzili śląscy przemysłowcy do etatyzmu, który nie stanowił zagrożenia dla silnego, skoncentrowanego sektora prywatnego. Jednak po połączeniu GZPG-H z „Lewiatanem” narracja uległa zmianie: górnoślaskie sfery przemysłowe poparły program CZPP. Włączyły się również w oskarżanie rządu o chęć zmiany ustroju, zwłaszcza w okresie przyspieszonej akcji polonizacji górnośląskiego przemysłu. W „Przemyśle i Handlu Górnośląskim” pojawiło się na ten temat sporo artykułów. Stanowisko kół przemysłowych wobec polityki ekonomicznej państwa było pełne sprzeczności. Z jednej strony krytykowano nadmierny interwencjonizm, szermując hasłami liberalizmu ekonomicznego, $z$ drugiej domagano się pomocy ze strony państwa. Widać to chociażby w corocznych sprawozdaniach z działalności Unii.

\footnotetext{
${ }^{5}$ Bank Gospodarstwa Krajowego był największą instytucją kredytową w Polsce. Finansował przede wszystkim inwestycje państwowe, udzielając kredytów długoterminowych.
} 


\section{Obrona procesu kartelizacji w ujęciu sfer przemysłowych}

Proces kartelizacji był następstwem rozwoju gospodarki kapitalistycznej. $\mathrm{Na}$ Górnym Śląsku, z uwagi na specyfikę regionu, dokonywał się szybko. Górnośląskie sfery przemysłowe podnosiły konieczność koncentracji produkcji $\mathrm{w}$ przemyśle ciężkim, metalowym i przetwórczym, zwracając uwage, aby przebiegała w atmosferze spokoju i przychylności czynników rządowych [Protokót z.posiedzenia..., 1932a]. Jeszcze przed kryzysem powstały np.: Ogólnopolska Konwencja Węglowa, Syndykat Polskich Hut Żelaznych, Centrocement. Państwo popierało ten proces, licząc na większy udział Polski w eksporcie i poprawę wskaźników makroekonomicznych. W latach wielkiego kryzysu gospodarczego kartelizacja przybrała na sile, występując głównie w formie związku pracodawców, kartelu bądź syndykatu. Przedsiębiorcy zawierali porozumienia dotyczące produkcji, cen i sprzedaży, aby mimo głębokiego załamania zapewnić sobie wysokie zyski. Na Górnym Śląsku powstały: „Wspólnota Interesów”, Katowicka Spółka Akcyjna dla Górnictwa i Hutnictwa, Huta „Pokój” Spółka Akcyjna, które regulowały prawie całość produkcji i zbytu wyrobów. Wraz ze wzrostem liczby karteli krajowych rósł także udział polskiego przemysłu w porozumieniach międzynarodowych, co przedstawia tabela 2.

TABELA 2

Liczba karteli krajowych i międzynarodowych w latach 1929-1935 (stan na 1 stycznia)

\begin{tabular}{|c|c|c|}
\hline \multicolumn{1}{|c|}{ Rok } & Kartele krajowe & Kartele międzynarodowe \\
\hline 1929 & 100 & 40 \\
\hline 1930 & 133 & 48 \\
\hline 1931 & 168 & 69 \\
\hline 1932 & 187 & 75 \\
\hline 1933 & 215 & 84 \\
\hline 1934 & 233 & 94 \\
\hline 1935 & 268 & 104 \\
\hline
\end{tabular}

Źródło: [Maty rocżnik statystyczny, 1937, s. 107].

Pod koniec kryzysu kartelizacja objęła ok. 60\% wytwórczości fabrycznej [Landau, 1974, s. 815]. W 1934 r. spółki z udziałem kapitału zagranicznego stanowiły zaledwie 14,8\% ogółu spółek akcyjnych, ale kontrolowały aż 52,4\% ich kapitału [Landau, Tomaszewski, 1982, s. 82]. Przynależność do karteli międzynarodowych chroniła rynek krajowy przed konkurencją zagraniczna, pozwalała otrzymać określoną pulę eksportowa, zapewniała bardziej stabilne i opłacalne ceny w wywozie, ale też przyznawała odszkodowanie za ograniczenie lub rezygnację z eksportu ${ }^{6}$.

${ }^{6}$ Największą siłę przebicia miały kartele węglowe i hutnicze [Landau, Roszkowski, 1995, s. 201]. 
Rząd popierał tworzenie porozumień monopolistycznych, często posiadając w nich swoje udziały, dzięki czemu organizacje te cieszyły się szczególną opieką państwa. Jednak w latach kryzysu sztywna polityka cenowa, opór wobec śmielszych prób nakręcania koniunktury i niezadowolenie społeczne zmieniły to nastawienie. Rząd kilkakrotnie podejmował akcje obniżki cen kartelowych. Pierwszą próbę podją na początku 1931 r., jednak nie przyniosła dobrych rezultatów, bo nie była to akcja przymusowa. Drugi raz, już z zastosowaniem środków administracyjno-gospodarczych, przystapiono do obniżki cen w październiku 1932 r. Trzecie podejście miało miejsce w 1935 r. Kartele, które nie dostosowały się do wprowadzonych obniżek, zostały rozwiązane (76 karteli, co stanowiło ok. 50\% całości).

W marcu 1933 r., mimo oporu ze strony „Lewiatana” [zob. Battaglia, 1929], Sejm uchwalił ustawę kartelową [Landau, Tomaszewski, 1982, s. 86], która wprowadzała nadzór Ministerstwa Przemysłu i Handlu nad kartelami, konieczność ich rejestracji i utworzenie Sąu Kartelowego. W. Ciechomski, radca prawny „Lewiatana”, zakwestionował zasadność przepisu o jawności rejestru kartelowego, co wynikało z obawy przed głębszą rządową kontrola monopoli. Krytyce poddawano również kolejne nowelizacje ustawy, traktując je jako kroki w kierunku osiagnnięcia absolutnej kontroli nad nimi.

Sferom wielkoprzemysłowym zależało na rozwoju porozumień monopolistycznych. Jeszcze przed kryzysem T. Sławiński, szef Biura Kartelowego, dowodził, że kartelizacja poprawia jakość produktów, usprawnia handel i eliminuje zbędne pośrednictwo [Sławiński, 1929, s. 7]. W latach kryzysu, kiedy wysokie i sztywne ceny kartelowe znalazły się na ostrzu krytyki, dowodził, że na dłuższą metę ich utrzymanie jest niemożliwe, ponieważ istnieje obawa powstania silnej konkurencji ze strony tzw. outsiderów [Sławiński, 1933, s. 420]. Odpierano coraz częściej pojawiające się oskarżenia, że kartele przyczyniły się do pogłębienia kryzysu. H. Gliwic [1935, s. 138-139] przekonywał, że „rozumne porozumienie w przemyśle daje w rezultacie lepsze wyniki w gospodarce niż dzika i nieunormowana konkurencja”. Bronił karteli, tłumacząc, że wprowadzają ład w gospodarkę i nie usztywniaja, lecz stabilizują ceny, co jest objawem zdrowym, „gdyż usuwają nieoczekiwane fluktuacje, których nie można uwzględnić w kalkulacji” [Gliwic, 1935, s. 136]. Sporo uwagi poświęcano kartelom międzynarodowym, które włączały Polskę do międzynarodowego układu gospodarczego, przyczyniały się do prawidłowej repartycji rynków, stabilizowały ceny na poziomie światowym i regulowały warunki sprzedaży, co prowadziło do obnizkki kosztów własnych i utrzymania dotychczasowego poziomu płac [Tennenbaum, 1929, s. 42]. W warunkach kryzysu pozwalały utrzymać aparat wytwórczy w należytych rozmiarach [Tennenbaum, 1931, s. 17]. Wskazywano ponadto na ich zalety w postaci:

- zwalczania anarchii w produkcji i nadużyć dumpingowych,

- gwarancji średnich zysków,

- zabezpieczenia pracowników przed skutkami kryzysu i bezrobociem,

- obniżania barier celnych,

- ułatwiania rozdziału kapitałów, pozyskiwania doświadczeń i wynalazków,

- gwarancji racjonalności [Battaglia, 1929, s. 122]. 
Podkreślano, że koncentracja stwarza warunki do wprowadzenia naukowej organizacji pracy i unowocześnienia metod produkcji, jednocześnie chroniąc przed ryzykiem. Na łamach „Przeglądu Gospodarczego” pojawiały się artykuły dowodzące korzyści wynikających z kartelizacji. $\mathrm{Na}$ przykładzie kartelu przędzalniczego Wierzbicki pokazywał, że takie formy organizacji przyczyniają się do utrzymania płac na stabilnym poziomie $\mathrm{i}$ - jeśli nawet jakiś niezorganizowany odbiorca zapłaci za przędzę trochę drożej - robotnik utrzyma dotychczasowy poziom zarobków. Podsumowywał, że jest to „prawdziwa zdobycz socjalna kartelizacji” [Wierzbicki, 1930, s. 767]. Jednocześnie krytykowano przymusowe kartele tworzone pod dyktando rządu, oskarżając je o nadmierną biurokrację, brak szybkiego reagowania w związku z koniecznością konsultacji decyzji z rządem, prostą drogę do socjalizacji zakładów przemysłowych [Ciechomski, 1932, s. 97].

„Lewiatan” odpierał ataki na zbyt wysokie ceny ustalane przez monopole, tłumacząc, że jako wektory postępu maja prawo do ustalania wyższych cen. Jednocześnie zrzucał im zbyt sztywne i wysokie koszty związane $z$ transportem, polityką socjalną i uciążliwym fiskalizmem. Tłumaczono, że nie mogą windować cen poprzez ograniczenie produkcji, bo wtedy konsument kupi towary substytucyjne. Ponadto każdy uczestnik np. syndykatu to potencjalny konkurent po rozpadnięciu się porozumienia, dlatego każdy woli zrezygnować z wyższych zysków, aby nie wzmocnić konkurenta [Sławiński, 1933, s. 418-420]. Widać tu wyraźnie, że chwytano się różnych sposobów, aby dowieść poprawności polityki cenowej. Wyższe ceny były swego rodzaju rekompensatą za utrzymanie produkcji na poziomie przekraczającym możliwość zbytu w kraju oraz ponoszenie skutków eksportu dumpingowego [Kofman, 1986, s. 85]. R. Battaglia dowodził, że dwudziestoprocentowa obniżka cen kartelowych przyniesie rolnictwu ulgę $\mathrm{w}$ granicach 1-4\%, należy więc dążyć do podniesienia cen artykułów rolnych [Battaglia, 1933, s. 385]. Ponadto „w związku z niedomaganiami kapitalizacyjnymi zniżki cen nie są zdolne wywołać (..) zwiększenia zbytu, tym samym także podtrzymać jaką taką kalkulację, a więc i produkcję w przemyśle skartelizowanym" [Battaglia, 1933, s. 412]. Podważano sposób liczenia wskaźników cen i ustalanie poziomu rozwarcia nożyc cen [Kofman, 1986, s. 89-90].

Sfery wielkoprzemysłowe broniły procesu monopolizacji gospodarki, podkreślając pozytywne skutki i przemilczając lub umniejszając negatywne. Nie ulega wattpliwości, że w latach kryzysu łatwiej było przetrwać w ramach różnych form porozumień. W ostatnich latach II Rzeczypospolitej, kiedy koniunktura uległa poprawie, ich liczba spadła.

\section{Podsumowanie}

Przedstawione syntetycznie stanowisko sfer wielkoprzemysłowych wobec największego w historii kryzysu gospodarczego i jego skutków składnia do następujących wniosków:

1. Sfery przemysłowe broniły własnych interesów, zabiegając o pomoc ze strony rządu; 
2. Kryzys nasilił proces monopolizacji przemysłu, pozwalając łagodniej przetrwać dekoniunkturę, co było widoczne zwłaszcza na Górnym Śląsku;

3. Każda akcja państwa zmierzająca w kierunku obniżenia cen przemysłu skartelizowanego spotykała się z oporem ze strony przemysłowców;

4. Wielki przemysł atakował etatyzm, oskarżając państwo o nieuczciwą konkurencję z sektorem prywatnym;

5. Krytyka polityki rządu nie przybrała zbyt ostrego tonu z uwagi na korzystanie z różnych form pomocy rządowej oraz powiązanie rządu ze sferami wielkoprzemysłowymi (przedstawiciele rządu zasiadali w radach nadzorczych firm).

\section{Literatura}

Battaglia R., 1929, Państwo a kartele, koncermy $i$ trusty, Wydawnictwo Izby Przemysłowo-Handlowej, Warszawa.

Bernadzikiewicz T., 1935, Przerosty etatyzmu. Uwagi o gospodarce państwowej w Polsce, Wydawnictwo Biblioteki Polskiej, Warszawa.

Bernadzikiewicz T., 1937, Mała reforma etaty:mu, Towarzystwo Wydawnicze Młodych Prawników i Ekonomistów, Warszawa.

Ciechomski W., 1932, Kartele a interwencja państwowa, „Przegląd Gospodarczy”, z. 3, s. 95-98.

Dangel J., 1936, Bieżqce zagadnienia gospodarcze w pracach Iz̧y Przemystowo-Handlowej w Katowicach w ostatnim kwartale, „Górnośląskie Wiadomości Gospodarcze”, nr 12, s. $1-2$.

Desyderaty pržemystu i handlu gómoślaskiego przedtożone p. Ministrowi Zarzyckiemu, 1932, „Górnośląskie Wiadomości Gospodarcze”, nr 12, s. 1-2.

Gliwic H., 1935, Kryzysowe rozważania ekonomiczne, Wydawnictwo Trzaska, Evert i Michalski, Drukarnia Narodowa, Kraków.

Grzyb M., 1978, Narodowościowo-polityczne aspekty przemian stosunków wtasnościonych $i$ kadronych w gómoślaskim przemysle w latach 1922-1939, Wydawnictwo Uniwersytetu Śląskiego, Katowice.

Ivanka, A., 1964, Wspomnienia skarbowca 1927-1945, PWN, Warszawa.

Kofman J., 1986, „Lewiatan” a podstawowe ragadnienia ekonomiczno-polityczne Drugiej Rzeçypospolitej, PWN, Warszawa.

Landau Z., 1974, Zasieg kartelizacii przemystu w Drugiej Rzecsypospolitej, „Kwartalnik Historyczny", nr 4, s. 799-817.

Landau Z., Roszkowski W., 1995, Polityka gospodarcza II RP i PRL, PWN, Warszawa.

Landau Z., Tomaszewski J., 1962, Zarys historii gospodarczej Polski 1918-1939, Wydawnictwo Książka i Wiedza, Warszawa.

Landau Z., Tomaszewski J., 1982, Gospodarka Polski miedsynojennej, t. III - Wielki kryzys 1930-1935, Wydawnictwo Książka i Wiedza, Warszawa.

Maly rocznik statystyczny, 1937, Główny Urząd Statystyczny, Warszawa.

Notatka dla Pana posła Jarczylka doreczona 18.04.1931 r., 1931, Urząd Wojewódzki Śląski/Przemysł i Handel, Archiwum Państwowe w Katowicach. 
Pabisz J., 1958, Zatrudnienie robotników za rewersem w byłym województwie ślaskim w latach traydziestych XX w., „Studia i Materiały z Dziejów Śląska”, t. II.

Pismo dyrekcji Polici w Katowicach do Urzedu Wojewódzkiego Ślaskiego, 1934, Wydział Bezpieczeństwa z dnia 21.11.1934 r., Dyrekcja Policji Katowice 370, nlb, Archiwum Państwowe w Katowicach.

Poznański J., 1933, O idee państwowa w prz̨emyśle polskim, Wydawnictwo Dom Książki Polskiej, Łódź - Warszawa.

Program gospodarczy Centralnego Zwiazku Przemystu Polskiego, 1933, na prawach rękopisu, Warszawa.

Protokót z.posiedzenia Komitetu Prezydialnego Unii Polskiego Przemystu Górniczo-Hutniczego z. 7.07.1932 r., 1932a, UPGH, Archiwum Państwowe w Katowicach.

Protokót z. posiedzenia Komitetu Prezydialnego Unii Polskiego Przemystu Górniczo-Hutniczego z. 17.10.1932 r., 1932b, UPGH, Archiwum Państwowe w Katowicach.

Protokót z. posiedzenia Komitetu Prezydialnego Unii Polskiego Przemystu Górniczo-Hutniczego z.9.06.1933 r., 1933, UPGH, Archiwum Państwowe w Katowicach.

Protokót z. posiedzenia Komitetu Prezydialnego Unii Polskiego Przemystu Górniczo-Hutniczego z.30.05.1934 r., 1934, UPGH, Archiwum Państwowe w Katowicach.

Protokót z.posiedzenia Komitetu Prezydialnego Unii Polskiego Przemystu Górniczo-Hutniczego z. 28.03 .1935 r., 1935a, UPGH, Archiwum Państwowe w Katowicach.

Protokót z.posiedzenia Komitetu Prezydialnego Unii Polskiego Przemystu Górniczo-Hutniczego z. 5.10.1935r., 1935b, UPGH, Archiwum Państwowe w Katowicach.

Roszkowski W., 2004, Historia Polski 1914-2004, Wydawnictwo Naukowe PWN, Warszawa.

Sławiński T., 1930, Z zagadnień kartelowych, „Gazeta Polska”, nr 299, s. 7.

Sławiński T., 1933, Zagadnienie elastyczności cen, [w:] Życie gospodarcze a ekonomika społeczna, Caro L. (red.), Polskie Towarzystwo Ekonomiczne, Lwów.

Sprawozdania Stenograficzne Sejmu Ślaskiego III kadencii, 1932, 14 posiedzenie 14.01.1932 r. Sprawozdanie z driatalności Górnoślaskiego Zwiazku Przemystowców Górniczo-Hutniczych za październik 1931 r., 1931, BHVK-5, Archiwum Państwowe w Katowicach, Katowice.

Sprawozdanie z. dziatalności Unii Polskiego Przemystu Górniczo-Hutniczego za rok 1933, Załacrnike do punktu 1 protokolu Zwyczajnego Walnego Zgromadzenia Członków Unii z 2.03.1934 r., 1934, UPGH, Archiwum Państwowe w Katowicach, Katowice.

Sprawozdanie z działalności Unii Polskiego Przemystu Górniczo-Hutniczego za rok 1934, Załacznik do punktu 1 protokolu Zwyczajnego Walnego Zgromadzenia Członków Unï z. 28.02.1935 r., 1935, UPGH, Archiwum Państwowe w Katowicach, Katowice.

Sprawozdanie z driatalności Unii Polskiego Przemystu Górniczo-Hutniczego za rok 1935 z. 21.02.1936 r., 1936, UPGH, Archiwum Państwowe w Katowicach, Katowice.

Starzyński S., 1932a, Braki programu Centralnego Zwiazku Przemystu Polskiego, „Polska

Gospodarcza”, nr 47, s. 1373-1382.

Starzyński S., 1932b, Program gospodarçy czy program zniżenia podatków?, „Polska Gospodarcza”, nr 50, s. 1473-1477.

Starzyński S., 1932c, Zamknięcie dyskusji „programowej”, „Polska Gospodarcza”, nr 51, s. $1505-1506$. 
Ślosarczyk A., 1936, Dwie miary - na marginesie sytuacji górnoślaskiego przemystu przetwórczego, „Górnośląskie Wiadomości Gospodarcze”, nr 19, s. 1-2.

Tennenbaum H., 1929, Ośrodki dyspozycii gospodarczej w Polsce, Instytut Wydawniczy „Biblioteka Polska”, Warszawa.

Tennenbaum H., 1931, Uwagi o krysyssie, Instytut Wydawniczy „Biblioteka Polska”, Warszawa.

Urzad Wojewódzki Ślaski/Przemyst i Handel, sygnatury: 52, 224, 232, 1303 II, 1310, 2500, 2635, Archiwum Państwowe w Katowicach.

Wierzbicki A., 1930, Mgławice i gwiazdy, „Przegląd Gospodarczy”, z. 18, s. 763-768.

Wierzbicki A., 1933, Program gospodarçy Lewiatana, Wydawnictwo Dom Książki Polskiej, Warszawa.

Zjazd driataçy gospodarcsych $i$ społecznych województwa ślaskiego zwołany przez. Narodowe Chrzésicijańskie Zjednoczenie Pracy (BBWR na Slasku) w dniu 17-go września 1933 r. w Katowicach, 1933, Główny Komitet Wykonawczy Narodowego Chrześcijańskiego Zjednoczenia Pracy, Katowice. 